Historia: Jurnal Program Studi Pendidikan Sejarah

Vol. 3 No. 2 (2018): 110-123

P-ISSN 2301-8305

E- ISSN 2599-0063

\title{
STUDI EFEKTIFITAS KEGIATAN MENGAJAR GURU JURUSAN IPS SMA NEGERI 05 BATAM
}

\section{TITLE STUDY OF EFFECTIVENESS OF TEACHERS TEACHING ACTIVITIES DEPARTMENT IPS SMA 05 BATAM}

\author{
Azimah \\ Program Studi Pendidikan Sejarah, Fakultas Keguruan dan Ilmu Pendidikan, Universitas Riau \\ Kepulauan, Indonesia \\ azimah@gmail.com
}

\begin{abstract}
Abstrak
Kurang menguasai bahan ajar, dan kurang pengelolaan program belajar mengajar, serta pengelolaan kelas yang kurang kondusif, sedikitnya penggunaan media dan sumber belajar dan kurang interaksi antara siswa dan guru dalam pembelajaran dan menilai prestasi siswa serta kurangnya dan kedisiplin dalam berkerja guru sehingga menyebabkan efektifitas pembelajaran SMA Negeri 05 Batam Tahun Pelajaran 2014/2015 menjadi kurang efektif. Tujuan penelitian ini adalah untuk meningkatkan kualitas guru menjadi lebih baik dan menjadi pembelajaran yang lebih efektif dan meningkatkan hasil belajar siswa. Hasil penelitian ini menunjukan bahwa guru-guru jurusan IPS di SMA 05 sudah melakukan dan melaksanakan kegiatan belajar mengajar secara efektif. Hal ini dibuktikan yaitu : 1) sudah menguasai bahan pengajaran. 2) sudah melakukan pengelolahan program belajar mengajar dengan baik. 3) sudah melakukan pengelolahan kelas dengan baik. 4) sudah menggunakan media dan sumber belajar saat proses pembelajaran. 5) sudah mampu dalam hal pengelolahan interaksi belajar mengajar dengan baik, baik antara guru dengan siswa maupun antara siswa dengan siswa. 6) sudah melaksanakan penilaian prestasi siswa dan terakhir. 7) guru sudah menerapkan disiplin kerja dalam pengajaran dengan baik.
\end{abstract}

Kata Kunci : Efektifitas, Kegiatan Mengajar, Guru Jurusan IPS

\begin{abstract}
Less master teaching materials, and lack of management of teaching and learning program, as well as classroom management that are less favorable, at least the use of media and learning and assessing student achievement and lack and discipline in the work of teachers, causing the effectiveness of lerning SMA 05 Batam domestic academic year 2014/2015 to be less effective. The purpose of this research is to improve the quality of teachers become better and become a more effective learning and improve student learning outcomes. These results indicate that teachers in high school majoring in social studies SMA 05 have done and implement effective teaching and learning activities. It is proven that : 1) have mastered teaching materials. 2) hove done management learning program well. 3) have done well management class. 4) already using media and learning resources during the learning process. 5) is capable of in terms of teaching and learning interaction management well, between teacher and students and between students and students. 6) has been conducting the assessment of student achievement and the lest. 7) teachers already working in the teaching discipline well.
\end{abstract}

Keywords: Effectiveness, Activity Teaching, Master Programs IPS 


\section{PENDAHULUAN}

Sekolah sebagai institusi pendidikan pada dasarnya bertujuan mempersiapkan siswa untuk dapat memecahkan masalah kehidupan masa sekarang dan yang akan datang dengan mengembangkan potensi-potensi yang dimilikinya. sekolah harus menyelenggarakan proses belajar mengajar dengan baik. Sekolah dituntut untuk menyusun rencana pendidikan yang dituangkan dalam program pendidikan dan dilaksanakan secara konsisten, agar pengaruhnya cukup besar terhadap penyelenggaraan dan hasil belajar di sekolah, hal ini tergantung dari berbagai faktor, salah satunya adalah guru yang memegang peranan penting

Guru dalam konteks pendidikan mempunyai peranan yang besar dan strategis, hal ini disebabkan guru yang berada di barisan terdepan dalam pelaksanaan pendidikan dan memegang peranan penting dalam keberhasilan implementasi kurikulum. Peningkatan kualitas pendidikan di Indonesia tidak cukup hanya dilakukan dengan pembenahan kurikulum saja, tetapi harus juga diikuti dengan peningkatan mutu guru di jenjang tingkat dasar dan menengah.

Proses pendidikan melibatkan unsur-unsur guru, siswa, sarana, metode, situasi kurikulum, tujuan, penilaian, dan manajemen. Guru harus mampu memanfaatkan semua unsur tersebut semaksimal mungkin agar tercapai pengajaran yang efektif yang pada akhirnya menghasilkan lulusan yang berkualitas. oleh sebab itu, guru harus memiliki kemampuan mengajar agar tujuan pendidikan dapat dicapai dengan efektif dan efesien. Guru perlu mempersiapkan diri secara baik dan dapat melaksanakan tugas-tugas yang menjadi tanggung jawabnya.Tugas dan tanggung jawab utama guru adalah mengelola pelajaran. Tugas tersebut harus dilaksanakan secara efektif, dinamis, efesien, dan positif, yang ditandai dengan terjadinya interaksi yang maksimal antara guru dan siswa, oleh karena itu, tugas guru diawali dengan perencanaan dan diakhiri dengan penilaian. Hasil dari penilaian akan dimanfaatkan sebagai umpan balik bagi perbaikan pengajaran selanjutnya.

Berkenaan dengan standar kompetensi guru, Direktorat Jenderal Pendidikan Nasional telah menyusun secara khusus rumusan standar kompetensi guru yang terdiri dari tiga komponen, yaitu 1.) Komponen kompetensi pengelolaan 
pembelajaran yang meliputi a) penyusunan rencana pembelajaran b) pelaksanaan interaksi belajar mengajar c) penilaian prestasi belajar peserta didik d) pelaksanaan tindak lanjut hasil penilaian 2) komponen kompetensi pengembangan potensi yaitu pengembangan-pengembangan profesi 3) komponen kompetensi penguasaan akademik yang meliputi a) pemahaman wawasan pendidikan dan b) penguasaan bahan kajian.

Menurut E. Mulyasa (dalam Majid, 2006:165) iklim belajar yang menyenangkan akan membangkitkan semangat dan menumbuhkan aktivitas serta kreativitas peserta didik. Iklim belajar yang menyenangkan di dalam kelas ini perlu dikuasai terutama untuk menciptakan dan mempertahankan kondisi kelas yang optimal guna terciptanya proses belajar mengajar yang serasi dan efektif.

Berdasarkan observasi penulisi pada tangal 8 Maret 2014, ternyata masih banyak guru mata pelajaran IPS yang mengajar belum mempersiapkan bahan pelajaran. Penulis juga melihat bahwa semangat kerja, disiplin kerja, kerja sama antara guru, dan pembinaan siswa masih kurang, hal ini terlihat dari adanya guru yang kurang menguasai bahan ajar, belum banyak memvariasikan metode mengajar yang baik untuk situasi belajar mengajar yang berbeda, kurang semangat dalam mengajar, tidak memanfaatkan waktu mengajar yang tersedia serta kurang mampu menciptakan kondisi kelas yang kondusif untuk optimalisasi belajar siswa.

Kondisi di atas kemungkinan gejala kurangnya kemampuan guru dalam penyelenggaraan pengajaran dan mungkin juga diperburuk oleh kurangnya disiplin dalam melaksanakan tugas dan juga kurang memahami arti tugas dan tanggung jawad atas amanah yang allah titipkan. Gejala-gejala yang diperlihatkan oleh guru dan siswa tersebut telah menyebabkan proses belajar mengajar yang tidak efektif. sehingga kedisplinan dalam menjalankan tugas kurang optimal dan kurang penguasaan bahan ajar serta kurang nya kumunikasi antara guru dan siswa, dan itu membuat jarak antara guru dan siswa dalam belajar sehingga membuat pembelajaran menjadi kurang efektif. Adapun permasalan diatas, peneliti berusaha mengkaji dari berbagai aspek pendidikan yang mempunyai pengaruh yang cukup berarti terhadap efektivitas mengajar guru. Pada akhirnya dapat meningkatkan prestasi belajar siswa. Akhirnya penulis ingin mengangkat permasalahan ini 
Historia: Jurnal Program Studi Pendidikan Sejarah

Vol. 3 No. 2 (2018): 110-123

P-ISSN 2301-8305

E- ISSN 2599-0063

dengan dengan judul Studi Efektifitas Kegiatan Mengajar Guru Jurusan IPS SMA Negeri 05 Batam

\section{METODOLOGI PENELITIAN}

Penelitian ini adalah penelitian kualitatif yang bersifat deskriptif. Yaitu untuk melihat, meninjau dan mengungkapkan apa yang ada saat penelitian. Tujuan dalam penelitian ini untuk membuat gambaran atau lukisan secara sistematis, akurat mengenai fakta-fakta serta hubungan antara masalah yang akan diselidiki ( M. Idrus, 2009 : 62). Sedangkan menurut Hillway ( dalam Mukhtar, 2013 :13) menggolongkan penelitian kualitatif deskriptif ini pada tiga katagori yaitu pengumpulan fakta (fact finding), penafsiran kritik ( critical interpretation), dan penelitian yang lengkap ( complete research).

Pengumpulan data adalah langkah sangat penting dalam sebuah penelitian ilmiah, karena data yang dihasilkan ini diharapkan dapat digunakan untuk menjawab sekaligus memecahkan permasalahan yang ada. Oleh karena itu data tersebut harus valid dan akurat. Adapun teknik pengumpulan data yang digunakan pada penelitian ini harus sesuai dengan sifat dan karakteristik penelitian yang dilakukan.

\section{Wawancara}

Wawancara atau interview digunakan sebagai teknik pengumpulan data apabila peneliti ingin melakukan studi pendahuluan untuk menemukan permasalahan yang harus diteliti, dan juga apabila peneliti ingin mengetahuai halhal dari responden yang lebih mendalam dan jumlah respondenya sedikit/kecil. Jenis wawancara pada penelitian ini adalah:

a. Wawancara terstruktur

Kegiatan wawancara terstruktur dilakukan peneliti dengan cara terlebih dahulu mempersiapkan bahan pertanyaan yang akan diajukan dalam wawancara nantinya. Dalam wawancara terstruktur ini peneliti harus mampu mengembangkan kemampuan mengkaji informasi dari informan. (Idrus, 2009 : 107). 
b. Wawancara tidak terstruktur

Dalam wawancara tidak terstruktur ini memberi peluang kepada peneliti untuk mengembangkan pertanyaan-pertanyaan penelitian. Peneliti sejak awal harus memiliki fokus pembicaran yang ingin ditanyakan sehingga seluruh wawancara yang dilakukan diarahkan pada masalah yang telah ditentukan. (Idrus, 2009 : 107).

\section{Observasi}

Observasi sebagai teknik pengumpulan data mempunya ciri yang spesifik bila dibandingkan dengan teknik yang lain, yaitu wawancara dan kuesioner. Jika wawancara dan kuesioner selalu berkomunikasi dengan orang, maka observasi tidak terbatas pada orang, tetapi juga objek-objek alam yang lain. Teknik pengumpulan data dengan obsevasi digunakan apabila penelitian berkenaan dengan perilaku manusia, proses kerja, gejala-gejala alam dan jika responden yang diamati tidak terlalu besar. Dalam penelitian ini digunakan observasi dengan pola pengamatan sebagai pemeran serta, maksudnya adalah peranan pengamatan secara terbuka diketahui oleh subjek, bahkan mungkin pengamat/peneliti didukung oleh subjek. Mengingat ada dukungan dari subjek, proses pengamatan ini memungkinkan memperoleh data yang dibutuhkan dalam penelitian (Sugiyono 2011 : 203). Teknik analisis data yang digunakan dalam penelitian ini adalah;

\section{Reduksi data}

Data yang diperoleh di lapangan jumlahnya cukup banyak untuk itu perlu dicatat secara teliti dan rinci. Semakin lama peneliti di lapangan, maka jumlah data akan semakin banyak, komplek, dan rumit, untuk itu perlu dilakukan analisa data melalui reduksi data. Mereduksi data artinya merangkum, memilih hal-hal yang pokok, memfokuskan pada hal-hal yang penting. Data yang tidak penting dibuat dalam bentuk simbol oleh peneliti. Dalam penelitian ini reduksi data lebih terfokus pada pendidikan keluarga dalam pembentukan karakter anak. Dalam mereduksi data, peneliti akan dipandu oleh tujuan yang akan dicapai. Tujuan utama dari penelitian kulitataif adalah pada temuan. Hal-hal yang dianggap asing, tidak dikenal dan tidak berpola itulah yang harus dijadikan perhatian melalui reduksi 
data. Reduksi data merupakan proses berfikir sensitif yang memerlukan kecerdasan dan keluasan serta kedalaman wawasan yang tinggi. (Sugiono, 2008 : 247).

2. Interpretasi Data

Interpretasi data merupakan suatu kegiatan yang mengabungkan hasil analisis dengan kenyataan, kriteria, atau standar tertentu untuk menemukan makna dari data yang dikumpulkan untuk menjawab permasalahan dalam penelitian yang sedang diperbaiki.

3. Kesimpulan analisis data dan interprestasi data.

Meskipun analisis data dan interpretasi data dilakukan sambil berjalan, tetapi harus dihindari analisis dan interpretasi data yang terlalu dini. Analisis dan interpretasi data diperlukan untuk merangkumkan apa yang telah diperoleh, menilai apakah data tersebut berbasis kenyataan, teliti, dan benar. Analisis dan interpretasi data juga diperlukan untuk memberi jawaban terhadap pertanyaan-pertanyaan yang diajukan. Hasil analisis dan interpretasi data akhirnya digunakan untuk memberikan masukan bagi perbaikan kegiatan bagi kegiatan penelitian. Pada akhir kegiatan penelitian, hasil analisis dan interpretasi data digunakan untuk menarik kesimpulan dalam lapangan.

\section{PEMBAHASAN}

Studi efektifitas atau pencapaian pembelajaran suatu sekolah dilihat dari kenerja guru tersebut kalau sekolah berhasil itu tak terlepas dari peranan guru yang baik dalam sekolah efektifitas mengajar guru. Menurut guru di SMA Negeri 05 batam : Efektifitas kegiatan mengajar guru di SMA Negeri 05 Batam sama dengan SMAN di sekolah -sekolah yang lain yang mengacu pada krikulum yang ada dan kegiatan mengajar juga sudah baik (wawancara ibu Rizki, 12: 2014) lain lagi menurut ibu Ade tentang efektifitas mengajar guru:

"saya tidak menilai orang tapi saya menilai diri saya sendiri saya rasa apapun yang dimiliki pasti bisa dilaksanakan karna pendidikan itu tidak hanya mengajar dilihat dari kualitasnya apalagi segi pengetahuanya 
Historia: Jurnal Program Studi Pendidikan Sejarah

Vol. 3 No. 2 (2018): 110-123

P-ISSN 2301-8305

E- ISSN 2599-0063

kalau dilihat dari berhasil tidaknya itu dari output nya atau dari tamatan atau kelulusan nya." ( wawancara : ibu ade, 12 :2014)

Dari pendapat diatas bahwa studi efektifitas mengajar guru tidak terlepas dari krikulum dan peranan guru terhadap hasil belajar siswa sehingga bisa mengasilakan lulusan dari sekolah tersebut. Peranan guru dalam kegiatan mengajar sangat penting dalam menunjang kegiatan belajar mengajar. Guru yang efektif juga harus mampu menguasai kemampuan sesuai dengan standar kompetensi yang telah ditetapkan dan berhasil meningkatkan hasil belajar siswa. karekterristik guru efektif dapat dilihat dari kenerjanya, bukan hanya dari hasil belajar siswa yang diharapkan, melainkan oleh proses pembelajarannya yang optimal.

Dalam proses pembelajaran guru harus memiliki kemampuan dalam menguasai bahan pengajaran. Bahan ajar adalah perlengkapan yang harus dimiliki oleh seorang guru. Guru sebagai pengajar lebih menekankan kepada tugas dalam merencanakan dan melaksanakan pengajaran. Dalam tugas ini, guru dituntut memiliki seperangkat pengetahuan dan keterampilan teknis mengajar. Namun yang paling penting guru harus menguasai ilmu atau bahan yang diajarkan.

Guru sebagai pembimbing memberikan tekanan tugas, memberikan bantuan kepada siswa dalam memecahkan masalah yang dihadapinya. Tugas ini merupakan aspek mendidik sebab tidak hanya berkenaan dengan penyampaian ilmu pengetahuan tetapi juga menyangkut pengembanan kepribadian dan pembentukan nilai-nilai siswa. Menurut salah seorang guru tentang penguasaan bahan ajar di SMA Negeri 05 Batam adalah sebagai berikut:

"Dalam menguasai bahan ajar dalam pembelajaran tergantung dari guru itu masing-masing. Artinya guru yang memegang suatu bidang studi sudah sesuai dengan latar belakang ilmu yang mereka miliki. Dalam menguasai bahan ajar guru harus terus belajar dan menggali ilmu sebanyak-banyaknya. Bukan berarti seorang guru itu telah menguasai semuanya. Tapi masih ada guru di SMAN 05 yang tidak menguasai bahan 
Historia: Jurnal Program Studi Pendidikan Sejarah

Vol. 3 No. 2 (2018): 110-123

P-ISSN 2301-8305

E- ISSN 2599-0063

yang diajarkan kepada siswa.”(wawancara: Ibu Rizki Purnama Sari, 12 juni 2014)

Untuk keefektifan guru mengajar penguasaan bahan ajar sangat menentukan keberhasilan seorang guru dalam menjalankan tugasnya mengajar. Berdasarkan hasil wawancara di atas ternyata di SMA Negeri 05 guru-guru harus menguasai bahan ajar dan guru-guru harus dituntut untuk mencari ilmu sebanyakbanyaknya guna diberikan kepada siswanya. Tapi di sekolah ini masih ada ditemukan guru yang masih tidak menguasai bahan ajar. Salah satu upaya yang dilakukan untuk memperbaiki hal tersebut adalah melakukan supervisi oleh kepala sekolah terhadap guru-guru di SMA Negeri 05 Batam, hal ini dilakukan guna memperbaiki segala kekurangan-kekurangan guru dalam proses pembelajaran. Dalam hal ini seperti yang dikatakan oleh seorang guru:

“Guru di SMA Negeri 05 masih ada yang belum menguasai bahan ajar, hal ini dapat dilihat dari hasil supervisi yang dilakukan oleh kepala sekolah. Namun guru yang disupervisi tersebut berterima kasih kepada kepala sekolah karena supervisi yang diadakan bukan untuk mencari kesalahan-kesalahan guru saat mengajar, tetapi untuk memperbaiki semua kekurangan-kekurangan saat proses pembelajaran. Hal yang dilakukan ini membuat guru sadar dengan segala kekurangan dan berterima kasih atas perbaikan yang diberikan kepada guru tersebut. “(wawancara: Ibu Mira Embun, 12 juni 2014)

Di samping harus menguasai bahan ajar, seorang guru juga harus dituntut untuk menyiapkan perangkat pembelajaran berupa Rencana Pelaksanaan Pembelajaran (RPP) dan silabus. Hal ini wajib dibuat oleh semua guru tanpa kecuali dan di SMA Negeri 05 juga menjadi keharusan untuk menyiapkan perangkat pembelajaran ini. Hal ini bertujuan agar guru dalam mengajar lebih terprogram dan terarah dalam melaksanakan proses pembelajaran, dengan adanya RPP dan silabus guru akan terbantu dan akan memberikan kemudahan dalam mengajar. Menurut Yulaelawati ( dalam Majid, 2006 : 39 ) Silabus merupakan 
Historia: Jurnal Program Studi Pendidikan Sejarah

Vol. 3 No. 2 (2018): 110-123

P-ISSN 2301-8305

E- ISSN 2599-0063

seperangkat recana serta pengaturan pelaksanaan pembelajaran dan penilaian yang disusun secara sistematis memuat komponen-kompenen yang saling berkaitan untuk mencapai penguasaan kompetensi dasar. Rpp dan juga Silabus adalah alat untuk membantu guru dalam mengajar lebih terarah dan lebih baik.

Masalah ini disampaikan oleh seorang guru: Tanpa RPP guru tidak bisa menjalankan tugasnya dengan baik. Karena RPP merupakan tuntunan dan acuan saat melakukan proses pembelajaran, (wawancara: Ibu Mimi, 12 Juni 2014).

Kalau berbicara pengelolaan program belajar mengajar maka itu tidak akan terlepas dari kurikulum. Kurikulum disusun untuk mencapai tujuan dalam pembelajaran. Menurut UU No. 2 Tahun 1989, kurikulum adalah seperangkat rencana dan pengetahuan mengenai isi dan bahan pelajaran serta cara yang digunakan sebagai pedoman penyelenggaraan kegiatan belajar mengajar. (Burhanuddin dkk, 2003 : 30).

Kurikulum sebagai rancangan pendidikan mempunyai peranan sangat penting dalam keseluruhan kegiatan pendidikan. Kurikulum adalah pemandu program belajar mengajar, pelaksanaan, dan hasil belajar mengajar yang hendak dicapai. Tanpa berpegeng pada kurikulum proses belajar mengajar tidak memiliki arah dan tujuan. Guru yang baik dan efektif serta guru yang profesional harus berpegang dan menguasai serta memahami kurikulum secara mendalam. Guru yang berhasil dalam pengajaran adalah guru yang mampu mempersiapkan siswa mencapai tujuan yang telah dirumuskan dalam kurikulum, pada saat ini SMA Negeri 05 Batam sudah menerapkan kurikulum yang berlaku secara nasional yaitu Kurikulum 2013. Di mana kurikulum ini lebih menekankan kepada tiga hal, yaitu afektif (sikap), baik sikap kepada Sang Pencipta maupun sikap terhadap sesama manusia, kemudian pengetahuan (kognitif), dan keterampilan (psikomotorik).

Seperti yang disampaikan oleh Ibu Mimi:

“ Di SMA Negeri 05 Batam sudah menerapkan kurikulum 2013 sama halnya dengan sekolah-sekolah yang ada di Indonesia. Kurikulum 2013 ini adalah penyempurnaan terhadap kurikulum-kurikulum yang telah ada sebelumnya. Guru-guru sudah mengajar berdasarkan atau berpedoman pada kurikulum 2013. Ini adalah salah satu bentuk peduli pemerintah 
Historia: Jurnal Program Studi Pendidikan Sejarah

Vol. 3 No. 2 (2018): 110-123

P-ISSN 2301-8305

E- ISSN 2599-0063

terhadap dunia pendidikan agar lebih maju dan lebih menyesuaikan dengan kondisi saat ini." (wawancara: Ibu Mimi, 12 Juni Mei 2014)

Dari hasil wawancara di atas dapat dilihat bahwa SMA Negeri 05 sudah memakai dan menerapkan kurikulum yang baru yaitu kurikulum 2013 dalam proses pembelajaran. Memang diakui bahwa kurikulum kita berubah-berubah, hal ini disebabkan oleh tuntutan masa ke masa. Kurikulum yang baru akan menyempurnakan kurikulum yang sudah ada. Kita tidak bisa mengatakan kurikulum yang baru lebih baik dari kurikulum yang lama. Karena pada hakekatnya kurikulum yang baru adalah melengkapi dari kurikulum yang sebelumnya, hanya saja ada penambahan atau menyempurnakan dari kurikulum yang sudah ada.

Tahapan terakhir dari strategi mengajar adalah tahap evaluasi atau penilaian dan tindak lanjut. Penilaian meliputi menyusun tes dan instrument penilaian lain, serta melaksanakan penilaian terhadap siswa secara objektif dan mengadakan pembelajaran remedial bagi siswa yang nilai nya kurang dari standar penilaian dan mengadakan pengayaan dalam pembelajaran. Tujuan tahapan ini untuk mengetahui tingkat keberhasilan dari kegiatan-kegiatan sebelumnya. tahap evaluasi ini bisa dilakukan dengan mengajukan atau membuat pertanyaan baik secara lisan maupun secara tulisan. Pertanyaan yang dibuat haruslah bersumber dari bahan pengajaran. Berhasil atau tidaknya tahapan ini dapat dilihat dari bisa atau tidaknya siswa menjawab pertanyaan yang diajukan guru. Masalah yang berhubungan dengan penilaian/evaluasi belajar berikut hasil wawancara yang disampaikan oleh Ibu Mira yang mengatakan:

"Penilaian itu adalah sangat perlu. Kita tidak bisa mengetahui apakah kita berhasil atau tidak tanpa adanya evaluasi atau penilaian. Dengan evaluasilah yaitu dengan membuat pertanyaan baik secara lisan maupun tertulis, maka kita akan tahu seberapa jahu anak menerima dan memahami apa yang telah dipelajari bersama. Jadi penilaian adalah penting dalam pembelajaran."( wawancara: Ibu Mira, 12 Juni 2014). 
Sebagai guru yang baik dan efektif adalah guru yang mampu mengadakan penilaian dan tindak lanjut. Dengan evaluasi kita akan dapat melihat anak yang mengerti dan yang tidak mengerti, anak yang mempunyai kemampuan tinggi dan anak yang biasa-biasa saja kemampuannya. Tentunya ini menjadi referensi dan pedoman bagi kita untuk memperbaiki semua yang berhubungan dengan proses pembelajaran, agar ada perbaikan untuk masa yang akan datang guna tercapainya tujuan bersama.

Jadi berdasarkan kedua pendapat di atas dapat disimpulkan bahwa penilaian prestasi terhadap siswa dalam proses pembelajaran adalah sangat penting dilakukan. Hal ini merupakan penentu berhasil atau tidaknya seorang guru dalam mengajar. Kalau hasil yang diperoleh tidak memuaskan dengan arti kata tidak bisa menjawab pertanyaan yang dibuat oleh guru, maka bisa dijadikan sebagai koreksi bagi guru yang mengajar untuk memperbaiki ke arah yang lebih baik lagi. Jangan sekali-kali guru mengatakan peserta didik yang tidak bisa, tapi gurulah yang harus koreksi diri di mana letak kekurangan dan kesalahannya. Guru yang baik dan efektif adalah guru yang mau belajar dari kesalahan dan belajar dari kesalahan tersebut. Guru yang efektif adalah guru yang berusaha untuk menjadi yang terbaik dari berbagi hal dan dapat mengwujutkan kualitas yang baik bagi perserta didik

\section{KESIMPULAN DAN SARAN}

\section{a. Kesimpulan}

Guru efektif (effective teacher) mempunyai seperangkat karakteristik atau ciri-ciri tertentu, salah satunya guru yang efektif adalah guru yang professional, di mana guru dituntut untuk memiliki lima komponen sebagai berikut:

1. Guru mempunyai kometmen pada siswa dan proses belajarnya

2. Guru menguasai secara mendalam bahan/ materi pelajaran yang diajarkan serta cara mengajarkannya kepada siswa.

3. Guru bertanggung jawab memantau hasil belajar siswa melalui berbagai tehnik evaluasi. 
Historia: Jurnal Program Studi Pendidikan Sejarah

Vol. 3 No. 2 (2018): 110-123

P-ISSN 2301-8305

E- ISSN 2599-0063

4. Guru mampu berfikir sistematis tentang apa yang dilakukannya dan belajar dari pengalamannya.

5. Guru soyogyanya merupakan bagian dari masayarakat dan lingkungan profesinya, misalnya di PGRI dan organisasiprofesi lainnya.

\section{b. Saran}

Dalam penelitian ini penulis hanya mengkaji tentang efektifitas mengajar guru di SMAN 05 Batam yaitu sesuai dengan kemampuan penulis. Sebenarnya masih banyak hal yang berhubungan dengan efektifitas guru yang bisa dibahas..

Tentunya masih banyak kekurangan-kekurangan di sana sini. Harapan penulis jadikanlah kekurangan ini sebagai cela dan peluang bagi penulis berikutnya untuk membuat yang lebih baik dari apa yang telah penulis teliti. Agar ke depannya penelitian dan penulisan yang berhubungan dengan efektifitas mengajar guru ini lebih sempurna yang tentunya akan menaikkan citra guru sebagai profesi yang mulia di tengah-tengah masyarakat. 
Historia: Jurnal Program Studi Pendidikan Sejarah

Vol. 3 No. 2 (2018): 110-123

P-ISSN 2301-8305

E- ISSN 2599-0063

\section{REFERENSI}

Majid, Abdul. 2006. Perencanaan Pembelajaran. Bandung: PT Remaja Rosda Karya

Sudijono, Anas. 2008. Pengantar Statistik Pendidikan. Jakarta: Raja Grafindo Persada

Arsyad, Azhar. 2007. Media Pembelajaran. Jakarta: Raja grafindo Persada.

Burhanuddin, et. al. 2003. Manajemen Pendidikan. Malang: Univ. Negeri Malang.

Buhary, Hasanuddin. 2007. Akuntabilitas Kinerja Pendidikan. Malang: Univ. Negeri Malang (UM Press).

Ismail, Kusmayadi. 2010. Kemahiran Interpersonal Untuk Guru. Bandung ; PT. Pribumi Makasar.

Asmani, Makmur, Jamal. 2011. 7 Tipe Aplikasi PAKEM (Pembelajaran Aktif, Kreatif, Efektif dan Menyenangkan) Menciptakan Metode Pembelajaran Yang Efektif dan Berkualitas. Yogyakarta: Diva Press.

Idris, Muhammad. 2009. Metode Penelitian Ilmu Sosial. Yogyakarta: Erlangga.

Christine, Maylanny. 2009. Pedagogi : Strategi dan Teknik Mengajar dengan Berkesan. Bandung: PT. Setia Purna Inves.

Idris dan Marno. 2010. Strategi dan Metode Pengajaran. Yogyakarta: Ar-Ruzz Media.

Mukhtar. 2013. Metode praktis penelitian deskriptif kualitatif. Jakarta: GP Press Group.

Sudjana, Nana. 2009. Dasar-dasar Proses Belajar Mengajar. Bandung: Sinar Baru Algensindo.

Susanti, Rini. 2011. Profesi Pendidikan. Batam: Universitas Riau Kepulauan.

Mudyahardja, Redja. 2001. Pengantar Pendidikan Sebuah Studi Awal tentang Dasar-Dasar Proses Belajar Mengajar. Bandung : Sinar Baru Algensindo.

Kosasih, Raflis dan Soetjipto. 1994. Profesi Keguruan. Jakarta: Departemen Pendidikan dan Kebudayaan

Sugiono, 2011. Metode Penelitian Pendidikan. Bandung: Alfabeta. 
Historia: Jurnal Program Studi Pendidikan Sejarah Vol. 3 No. 2 (2018): 110-123

P-ISSN 2301-8305

E- ISSN 2599-0063

Sugiono, 2008. Metode penelitian kuantitatif kualitatif dan R\&D. Bandung : Alfabeta.

Sukardi, 2011. Metodologi Penelitian Pendidikan. Jakarta ; Bumi Aksara.

Sagala, Syaiful. 2009. Manajemen Strategi dalam Peningkatan Mutu Pendidikan. Bandung : Alfabeta

Suparlan. 2003. Menjadi Guru Efektif. Yogyakarta ; Hikayat Publishing

Wahyudi. 2009. Kepemimpinan Kepala Sekolah Dalam Organisasi Pembelajaran (Learning Organization) .Pontianak : Alfabet 